\title{
Effectiveness of treatment of newly diagnosed hypertension in family medicine practices in South Croatia
}

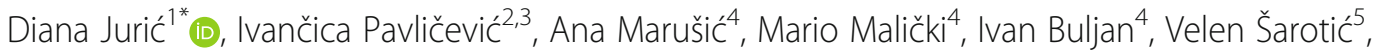
Nataša Mrduljaš-Đujić ${ }^{2,6}$, Ante Komparak ${ }^{7}$, Miona Vujević ${ }^{8}$, Danijela De Micheli-Vitturi ${ }^{3}$, Pjera Šušnjar ${ }^{9}$, Tina Puljiz ${ }^{10}$, Minka Jerčić ${ }^{11}$, Dario Leskur ${ }^{12}$ and Matko Marušić ${ }^{4}$

\begin{abstract}
Background: Uncontrolled blood pressure remains an urgent issue in clinical practice worldwide. This study aimed to compare the characteristics and effectiveness of hypertension control in family medicine pratice in the first treatment year, in relation to the geographical position, socio-economic standard, and access to medical services and public pharmacies in urban, rural and island environments (city of Split vs. Dalmatian Hinterland vs. islands in Southern Croatia).

Methods: A historical cohort study included 213 patients diagnosed from 2008 to 2014 with essential arterial hypertension (AH) and without related complications or diabetes mellitus. Each patient was followed up for 365 days from the visit when the diagnosis of hypertension was ascertained. Normotension was defined as arterial pressure $<140 / 90 \mathrm{mmHg}$. The annual cost of drugs prescribed for treating newly diagnosed hypertensive patient and the total price for defined daily dose per patient were also evaluated.

Results: More than half patients achieved normotension within a year from the initial diagnosis in all family medicine practices (57.3\%), without significant differences among the three geographic regions $(P=0.981)$. Higher initial systolic blood pressure was a positive predictive prognostic factor on achieveing normotension (odds ratio (OR) 0.96, 95\% confidence interval 0.95-0.98). ACE inhibitors were the most commonly prescribed antihypertensive agents in monotherapy (35.1\%), as well as considering overall prescriptions (25.2\%). Calcium channel blockers were the most commonly prescribed initial BP-lowering single agents in urban areas (28.6\%), whereas angiotensin-converting enzyme inhibitors were more common in rural $(28.0 \%)$ and island areas $(22.7 \%)(P=0.037)$. The median annual antihypertensive drug cost was 169.4 (95\% Cl 151.5-201.8) Croatian kunas and was similar across the study sites.
\end{abstract}

Conclusion: Multiple antihypertensive drugs, prescribed in accordance with the guidelines, lead to similar pharmacological effects. Primary care physicians seem to be able to overcome potential interfering socioeconomic factors and successfully achieve normotension in newly diagnosed patients with uncomplicated $\mathrm{AH}$ after 1 year of treatment.

Keywords: Blood pressure, Arterial hypertension, Control, Normotension, Urban, Rural, Island, Hypertension treatment

\footnotetext{
*Correspondence: diana.juric26@gmail.com; djuric@mefst.hr

'Department of Pharmacology, University of Split School of Medicine,

Šoltanska 2, Split, Croatia

Full list of author information is available at the end of the article
}

(c) The Author(s). 2019 Open Access This article is distributed under the terms of the Creative Commons Attribution 4.0 International License (http://creativecommons.org/licenses/by/4.0/), which permits unrestricted use, distribution, and reproduction in any medium, provided you give appropriate credit to the original author(s) and the source, provide a link to the Creative Commons license, and indicate if changes were made. The Creative Commons Public Domain Dedication waiver (http://creativecommons.org/publicdomain/zero/1.0/) applies to the data made available in this article, unless otherwise stated. 


\section{Background}

High systolic blood pressure (BP) was one of the most frequent Level 3 risk factors for global burden of disease according to the systematic analysis published in 2016 [1]. The estimated number of adults with elevated BP in 2015 increased to 1.13 bilion, in comparison to 594 milion in 1975 [2]. A 2015 systematic review and meta-analysis, which included data on almost 1.5 million adults from 45 countries, reported $32.3 \%$ overall prevalence of arterial hypertension (AH) [3]. Similar prevalence of $30-55 \%$ was also found in other recent studies [4-10]. The factors influencing the variations in $\mathrm{AH}$ prevalence may be related to the geographical region, degree of urbanization and changing lifestyles [11]. The prevalence in rural areas fluctuate from very low in some studies $[12,13]$ to significantly higher than in urban areas in the others $[14,15]$. Strict BP control in order to prevent cardiovascular morbidity and mortality is recommended in all guidelines for the management of $\mathrm{AH}$ [16-20]. Most of data on BP control are obtained from population-based studies, national surveys or secondary care [21], whilst the data on assessment of regulating $\mathrm{AH}$ in the primary care settings are sparse [22-24]. However, the data collected in the 2010 National Ambulatory Medical Care Survey, in which hypertension was identified as the most frequently diagnosed condition at physician practice visits, underline the importance of primary health care in prevention, detection and control of high blood pressure [25]. In 2001, cardiovascular diseases were the most common chronic diseases recorded among Croatian family medicine practices [26]. Croatia is among top-ranked countries worldwide according to the prevalence of hypertension, with the highest mean systolic BP in men in 2015 reaching $137.5 \mathrm{mmHg}$ (95\% CI 131.2-143.8) [2]. The aim of our study was to assess the treatment and control of uncomplicated $\mathrm{AH}$ at the primary health care level in the context of different impacting conditions, such as better transportation accessibility, higher socio-economic standard and educational level in urban settings vs. geographically isolation and poorer access to medical services and public pharmacies in hinterland rural areas and islands of South Croatia.

\section{Methods}

\section{Study participants and data collection}

This historical cohort study included patients of either sex, aged $\geq 18$, whose arterial hypertension was first diagnosed from 2008 to 2014. According to clinical practice guidelines for the managament of $\mathrm{AH}$ valid in the time of our research, participants with the mean systolic arterial pressure $\geq 140 \mathrm{mmHg}$ and/or diastolic arterial pressure $\geq$ $90 \mathrm{mmHg}$ were classified as hypertensive [16-19], and included in the study. Sitting blood pressure had to be estimated in family medicine practices (except in cases of medical specialists' involvement in the diagnosis) based on a standardized protocol using oscillometric or auscultatory semiautomatic sphygmomanometers [17].

Hypertensive patients were not included in the study if they had 1) AH diagnosed in the period before 2008, 2) incomplete medical records for the studied period, and 3) serious acute and chronic diseases (acute myocardial infarction, cerebrovascular insult and malignant tumors, respectively). Since various abnormalities present in diabetes mellitus and arterial hypertension have significant pathogenetic contribution to the development and exacerbation of each other [27, 28], and because diabetes mellitus is more than twice prevalent in patients with essential hypertension than in normotensive patients [29, 30], patients with diabetes mellitus present prior to the diagnosis of arterial hypertension were excluded from the study.

The data were collected from family medicine offices files. Included practices were long-standing and led by a single-physician, who had individual contracts with the mandatory national Croatian Health Insurance Fund (CHIF). Family medicine practices in Croatia provide health care for an average 1840 patients, with minimum 1275 and maximum 2125 patients allowed [31].

Each patient was followed for 1 year after the initial diagnosis. The urban area included the city of Split and the rural area included the town of Imotski and municipalities Lećevica, Muć, and Runovići (Dalmatian Hinterland). Southern Croatian islands of Brač (municipalities Postira and Pučišća) and Korčula (town of Korčula) represented the island environment (Table 1). The main demographic data included the place of residence (urban, rural, island), age, gender, employment status, marital status, educational level and comorbidities.

\section{Main outcome measures}

The primary outcome measures were: 1) rate of achieving normotension after one-year treatment, 2) mean arterial pressure (MAP) before and after one-year treatment, and 3) complications of treatment, including cardiovascular complications and side effects of medications. The achieved blood pressure control was defined as the proportion of participants whose average systolic and diastolic blood pressure 365 days after the initial diagnosis (with a deviation of \pm 15 days, depending on the scheduled patient visits to the family medicine office) was less than $140 / 90 \mathrm{mmHg}$. The secondary outcome measures were: 1) choice of initial treatment, 2) diagnosis by a physician or a medical specialist (usually an internist), 3) length of sick leave days, 4) full or partial coverage of prescribed medications by the national insurance fund, CHIF, 5) total price for defined daily dose (DDD) of all prescribed medications per each patient, and 6) total annual cost of prescribed drugs for treating one newly diagnosed hypertensive patient. 
Table 1 List of family medicine practices included in the study ${ }^{a}$

\begin{tabular}{llll}
\hline Family medicine practice & Total number of included patients & Total number of insured $^{\text {b }}$ & 1709 Total population $^{\text {b }}$ \\
\hline Urban 1: Split 1 & 18 & 1509 \\
Urban 2: Split 2 & 46 & 1851 & 102 \\
Hinterland 1: Imotski & 17 & 2267 & 10,764 \\
Hinderland 2: Lećevica & 38 & 326 & 583 \\
Hinterland 3: Donji Muć & 8 & 859 & 3882 \\
Hinterland 4: Runovići & 15 & 1781 & 2416 \\
Island 1: Postira & 31 & 1259 & 1559 \\
Island 2: Pučišća & 14 & 908 & 2171 \\
Island 3: Korčula & 26 & 1026 & 5663 \\
\hline
\end{tabular}

asource: Portal of the Open Data of the Republic of Croatia and the Census of Population, 2011, Croatian Central Bureau of Statistics

${ }^{b}$ Data from the Croatian Census of Population, 2011

CHIF provides the mandatory health insurance in Croatia, with the obligatory health insurance contributions of employed citizens as the major source of its revenue [32]. This public fund is responsible for health policy implementation, funding and control of health services [33]. There are two reimbursement lists compiled by the CHIF, the Croatian National Medicine Basic Reimbursement List, with both hospital and retail prescription drugs, fully covered by mandatory insurance, and the Croatian National Medicine Supplementary Reimbursement List, where patients have to pay the fraction of the cost, from 10 to $90 \%$. Reimbursement decisions are made according to the criteria established in the Ordinance of Ministry of Health from 2013 [34]. Drugs covered by mandatory insurance can be prescribed only by primary care physicians in the public sector who are contractual partners with the CHIF [26].

To estimate the cost of antihypertensive drugs prescribed during 1 year, original drug packacking prices (including VAT) and prices for defined daily dose (DDD) were taken from the Basic and the Supplementary List, which were valid during data extraction, both in force since 30 May 2015 until 19 July 2015 for the Basic List and until 19 August 2015 for the Supplementary List [35]. The total annual cost of prescribed medications was calculated from the original drug packaging price (including VAT) and the number of prescribed original drug packagings, and the total price for DDD was defined as the sum of all prices for DDD of all medications prescribed to each patient during one-year pharmacotherapy.

We also recorded whether the initial antihypertensive treatment focused on lifestyle changes (Dietary Approaches to Stop Hypertension) [36] without concomitant drug therapy, or whether pharmacological treatment was started immediately after the diagnosis. Prescribed first-line BP-lowering agents were compared with the recommendations from clinical practice guidelines [16-20]. The data on the total number of daily pills (both antihypertensives and non-anithypertensive drugs for all other present comorbidities) and the annual number of drugs per patient were collected from patients' medical records.

\section{Statistical analysis}

The data were presented as a median or a mean, with 95\% confidence interval (CI), depending on the data distribution; the normality of distribution was checked using the Kolmogorov-Smirnov tests. For the comparison of categorical variables we used $\chi^{2}$ test. Patients' age, MAP before and after one-year treatment, number of visits to the family medicine office and sick leave days were compared according to the patients' place of residence, using analysis of variance (ANOVA) with the post-hoc Scheffé test. Kruskal-Wallis test and post-hoc Mann-Whitney $U$ test were used for the median comparison of the total annual number of prescribed medications per patient and the total annual cost of drugs prescribed for treating one newly diagnosed hypertensive patient by a physician. Mann-Whitney and $x^{2}$ test were used to determine which variables were significantly different in controlled and uncontrolled hypertensive patients; those variables were further analysed by logistic regression. $P$-values less than 0.05 were considered statistically significant. All statistical analyses were performed using MedCalc, version 12.5 (MedCalc Software, Mariakerke, Belgium).

\section{Results}

Characteristics of newly diagnosed hypertensive patients

The final study sample included 213 patients; 64 (30.0\%) from urban, 78 (36.6\%) from rural and 71 (33.3\%) from island environment of South Croatia (Table 1). Female patients were predominant in the urban area $(n=41$, 64.1\%), where patients had significantly higher prevalence of dyslipidemia, the most common comorbidity (50.0\% vs. $12.1 \%$ in the rural area and $26.1 \%$ on the islands; $P=0.003$, Table 2). The rural area had almost four times more unemployed patients than in other 
Table 2 General features of hypertensive patients in urban, rural and island environment of South Croatia

\begin{tabular}{|c|c|c|c|c|}
\hline General features & Urban area $(n=64)$ & Rural area $(n=78)$ & Island area $(n=71)$ & $p^{a}$ \\
\hline Age; years (mean, 95\% Cl) & $60(57-63)$ & $57(54-59)$ & $57(54-60)$ & $0.319^{b}$ \\
\hline No data $(\mathrm{n},(\%))$ & $0(0.0)$ & $1(1.3)$ & $1(1.4)$ & \\
\hline \multicolumn{5}{|l|}{ Sex $(n,(\%)$} \\
\hline Men & $23(35.9)$ & $45(57.7)$ & $39(54.9)$ & \multirow[t]{2}{*}{0.022} \\
\hline Women & $41(64.1)$ & $33(42.3)$ & $32(45.1)$ & \\
\hline \multicolumn{5}{|l|}{ Employment status (n, (\%)) } \\
\hline Employed & $24(37.5)$ & $23(29.5)$ & $40(56.3)$ & \multirow[t]{4}{*}{$<0.001$} \\
\hline Unemployed & $6(9.4)$ & $34(43.6)$ & $6(8.5)$ & \\
\hline Pensioner & $31(48.4)$ & $21(26.9)$ & $24(33.8)$ & \\
\hline No data & $3(4.7)$ & $0(0.0)$ & $1(1.4)$ & \\
\hline \multicolumn{5}{|l|}{ Marital status (n, (\%)) } \\
\hline Married & $39(60.9)$ & $51(65.4)$ & $52(73.2)$ & \multirow[t]{5}{*}{0.283} \\
\hline Divorced & $3(4.7)$ & $1(1.3)$ & $0(0.0)$ & \\
\hline Unmarried & $7(10.9)$ & $15(19.2)$ & $11(15.5)$ & \\
\hline Widow/er & $11(17.2)$ & $10(12.8)$ & $8(11.3)$ & \\
\hline No data & $4(6.3)$ & $1(1.3)$ & $0(0.0)$ & \\
\hline \multicolumn{5}{|l|}{ Educational level (n, (\%)) } \\
\hline Primary education & $7(10.9)$ & $29(37.2)$ & $18(25.4)$ & \multirow[t]{5}{*}{0.004} \\
\hline High school graduate & $39(60.9)$ & $43(55.1)$ & $38(53.5)$ & \\
\hline Postsecondary diploma & $3(4.7)$ & $2(2.6)$ & $10(14.1)$ & \\
\hline University degree & $7(10.9)$ & $4(5.1)$ & $4(5.6)$ & \\
\hline No data & $8(12.5)$ & $0(0.0)$ & $1(1.4)$ & \\
\hline \multicolumn{5}{|l|}{ Comorbidities (n, (\%)) } \\
\hline Multiple comorbidities & $17(50.0)$ & $29(87.9)$ & $17(73.9)$ & \multirow[t]{2}{*}{0.003} \\
\hline Dyslipidemia & $17(50.0)$ & $4(12.1)$ & $6(26.1)$ & \\
\hline
\end{tabular}

${ }^{a} x^{2}$ test

${ }^{\mathrm{b} A N O V A}$

areas $(P<0.001)$ and the highest rate of patients with only primary education $(P=0.004$, Table 2$)$.

\section{Hypertension control}

The patients in the whole sample showed a significant reduction in systolic and diastolic blood pressure (paired samples T-test, $\mathrm{P}<0.001)$. There were no differences in the participants with average systolic and diastolic blood pressure lower than 140/90 mmHg: 37 (57.8\%) in urban, $45(57.7 \%)$ in rural and $40(56.3 \%)$ in island environment $(P=0.981$, Table 3$)$. Only the diastolic blood pressure differed after 1 year and was the lowest in island areas (82 mmHg (80.8-84.0 mmHg) vs. $85 \mathrm{mmHg}(83.1-86.8$ $\mathrm{mmHg})$ in rural areas and $86 \mathrm{mmHg}(84.4-87.6 \mathrm{mmHg})$ in the city; $P=0.012$, Table 3 ). Medical specialists from secondary or tertiary health care settings more often partcipated in the diagnosis and/or prescribing the first medication in the urban area $(n=13,20.3 \%)$ compared to the rural $(n=4,5.1 \%)$ and island areas $(n=8,11.3 \%)$ $(P=0.020$, Table 4$)$. There were no differences regarding general features of patients who achieved normotension and who did not (see Additional file 1: Table S1), although significantly higher proportion of patients had normal BP after 1 year $(P=0.034)$. Analysis of the outcome variables in logistic regression model indicated higher initial systolic blood pressure as a positive predictive prognostic factor on achieveing normotension (OR 0.96, 95\% CI 0.95-0.98, $\mathrm{R}^{2}=0.06323$ ).

\section{Cost of prescribed drugs}

The median annual cost of antihypertensive drugs for treating newly diagnosed hypertensive patient was 169.4 (95\% CI 151.5-201.8) Croatian kunas. Only a single physician from the rural area had significantly higher annual cost than the others $(290.3,95 \% \mathrm{CI}=214.1-394.7$ Croatian kunas, $P<0.001)$. Individual physicians did not differ in prescribing medications from two Croatian $\mathrm{Na}$ tional Medicine Reimbursement Lists $(P=0.286$, Table $4)$ and in the total cost for defined daily dose of all prescribed medications per each patient $(P=0.228$, Table 4$)$. 
Table 3 Primary outcome measures for assessment of the effectiveness of AH treatment in South Croatia

\begin{tabular}{|c|c|c|c|c|}
\hline Primary outcome measure & Urban area $(n=64)$ & Rural area $(n=78)$ & Island area $(n=71)$ & $P$ \\
\hline Rate of acheiving normotension ( $\mathrm{n},(\%))$ & $37(57.8)$ & $45(57.7)$ & $40(56.3)$ & $0.981^{a}$ \\
\hline \multicolumn{5}{|c|}{ Arterial pressure $[\mathrm{mmHg}$; mean, $95 \% \mathrm{Cl}]$ before treatment: } \\
\hline Systolic arterial pressure & $158.9(156.1-161.7)$ & $162.4(158.8-165.9)$ & $159.2(155.2-163.2)$ & $>0.05^{b}$ \\
\hline Diastolic arterial pressure & $96.0(94.0-97.9)$ & $97.5(95.5-99.5)$ & $97.8(95.7-99.8)$ & $>0.05^{b}$ \\
\hline \multicolumn{5}{|c|}{ Arterial pressure [mmHg; mean, $95 \% \mathrm{Cl}]$ after one-year treatment ${ }^{\mathrm{c}}$ : } \\
\hline Systolic arterial pressure & $141.0(138.1-143.8)$ & $137.5(134.7-140.2)$ & $136.6(134.1-139.2)$ & $0.073^{b}$ \\
\hline Diastolic arterial pressure & $86.0(84.4-87.6)$ & $84.9(83.1-86.8)$ & $82.4(80.8-84.0)$ & $0.012^{b}$ \\
\hline Treatment complications (n, (\%)) & $4(6.3)$ & $7(9.0)$ & $6(8.5)$ & $0.838^{\mathrm{a}}$ \\
\hline No data & $1(1.5)$ & $0(0.0)$ & $0(0.0)$ & \\
\hline
\end{tabular}

${ }^{a} x^{2}$ test

'Two-way ANOVA

'Because of the historical study design this time had a deviation of \pm 15 days

\section{Drug prescriptions}

Pharmacotherapy approaches to the first-line treatment differed in urban, rural and island environment $(P=0.037$, Table 5). Calcium channel blockers were the most commonly prescribed initial BP-lowering single agents in urban areas $(n=16,28.6 \%)$, whereas angiotensin-converting enzyme inhibitors (ACEI) were more common in rural $(n=21,28.0 \%)$ and island areas $(n=15,22.7 \%)$.

Within the first year of therapy, a total of 77 patients (39.1\%) out of 197 patients who received pharmacological therapy received monotherapy, whereas 120 patients (60.9\%, Table 6) were on multiple drug therapy. In the monotherapy group, ACEI were the most commonly prescribed ( $n=27,35.1 \%), \beta$-blockers ranked second $(n=22$, $28.6 \%)$, followed by calcium channel blockers $(n=18$, $23.4 \%)$ and thiazide-like diuretics $(n=9,11.7 \%$, Table 6). Among 54 patients who achieved normotension with monotherapy, lisinopril, amlodipine and bisoprolol were the most frequently prescribed $(n=11,20.4 \%$ for each, respectively).

Table 4 Secondary outcome measures for assessment of the effectiveness of AH treatment in South Croatia

\begin{tabular}{|c|c|c|c|c|}
\hline Secondary outcome measures & Urban area $(n=64)$ & Rural area $(n=78)$ & Island area $(n=71)$ & $P^{a}$ \\
\hline \multicolumn{5}{|l|}{ Initial treatment $(n, \%)$ : } \\
\hline Non-pharmacological & $14(21.9)$ & $8(10.3)$ & $18(25.4)$ & \multirow[t]{3}{*}{0.043} \\
\hline Pharmacological & $50(78.1)$ & $70(89.7)$ & $52(73.2)$ & \\
\hline No data & $0(0.0)$ & $0(0.0)$ & $1(1.4)$ & \\
\hline \multicolumn{5}{|l|}{ Prescribing first medication ( $n, \%)$ : } \\
\hline Physician & $51(79.7)$ & $74(94.9)$ & $62(87.3)$ & \multirow[t]{3}{*}{0.020} \\
\hline Medical specialist & $13(20.3)$ & $4(5.1)$ & $8(11.3)$ & \\
\hline No data & $0(0.0)$ & $0(0.0)$ & $1(1.4)$ & \\
\hline \multicolumn{5}{|c|}{ Sick leave days beacause of arterial hypertension (mean, 95\% Cl) } \\
\hline Total number of days ${ }^{\mathrm{b}}$ & $1.8(0.0-4.2)$ & $3.6(0.0-10.0)$ & $1.2(0.0-2.6)$ & $0.692^{c}$ \\
\hline \multicolumn{5}{|c|}{ Proportion (n, \%) of patients with prescribed medications from the List(s) ${ }^{d}$} \\
\hline Basic & $35(64.8)$ & $49(70.0)$ & $36(60.0)$ & \multirow[t]{3}{*}{0.286} \\
\hline Supplementary & $11(20.4)$ & $6(8.6)$ & $9(15.0)$ & \\
\hline Basic + Supplementary & $8(14.8)$ & $15(21.4)$ & $15(25.0)$ & \\
\hline \multicolumn{5}{|c|}{ Total price for DDD per patient (median, HRK, interquartile range) ${ }^{e}$} \\
\hline Total price for DDD & $0.91(0.49-1.24)$ & $0.96(0.45-1.55)$ & $1.19(0.49-2.06)$ & $0.228^{f}$ \\
\hline
\end{tabular}

${ }^{d}$ Excluded participants without pharmacological treatment during the first treatment year $(n=16)$ and with incomplete data on medications required for analysis $(n=13)$

${ }^{\mathrm{e}}$ The median of all calculated sums of prices for defined daily dose (DDD) in Croatian kuna (HRK) of all medications prescribed to each patient during one-year treatment. Excluded participants without pharmacological treatment during the first treatment year $(n=16)$ and with incomplete data on medications required for analysis $(n=13)$

fKruskal-Wallis test 
Table 5 Characteristics of antihypertensive pharmacotherapy in urban, rural and island environment of South Croatia

\begin{tabular}{|c|c|c|c|c|}
\hline Pharmacotherapy & Urban area $(n=56)^{a}$ & Rural area $(n=75)^{a}$ & Island area $(n=66)^{a}$ & $P^{b}$ \\
\hline \multicolumn{5}{|l|}{ First-line treatment $(n,(\%))$} \\
\hline 1. Diuretics & $3(5.4)$ & $8(10.7)$ & $1(1.5)$ & 0.037 \\
\hline 2. ACE inhibitors (ACEI) & $14(25.0)$ & $21(28.0)$ & $15(22.7)$ & \\
\hline 3. Calcium channel blockers (CCB) & $16(28.6)$ & $5(6.7)$ & $9(13.6)$ & \\
\hline 4. Angiotensin II receptor blockers (ARB) & $0(0.0)$ & $0(0.0)$ & $1(1.5)$ & \\
\hline 5. $\beta$-adrenergic receptor blockers (BB) & $5(8.9)$ & $8(10.7)$ & $14(21.2)$ & \\
\hline 7. Fixed-dose combination: ${ }^{c}$ & $8(14.3)$ & $12(16.0)$ & $7(10.6)$ & \\
\hline ACEI + diuretic & $5(8.9)$ & $9(12.0)$ & $5(7.6)$ & \\
\hline $\mathrm{BB}+$ diuretic & $2(3.6)$ & $0(0.0)$ & $2(3.0)$ & \\
\hline$A R B+$ diuretic & $0(0)$ & $1(1.3)$ & $0(0.0)$ & \\
\hline$A C E I+C C B$ & $1(1.8)$ & $2(2.7)$ & $0(0.0)$ & \\
\hline 8. $>1$ medications $(2 \text { or } 3)^{c}$ & $10(17.9)$ & $21(28.0)$ & $19(28.8)$ & \\
\hline \multicolumn{5}{|l|}{ One-year treatment (median, 95\% Cl) } \\
\hline Total daily number of pills per patient ${ }^{d}$ & $1.5(1.0-2.0)$ & $1.5(1.0-2.0)$ & $2(1.0-2.6)$ & 0.217 \\
\hline Total annual number of drugs per patient & $1(1.0-2.0)$ & $2(1.0-2.0)$ & $1(1.0-2.0)$ & $0.135^{\mathrm{e}}$ \\
\hline
\end{tabular}

${ }^{a}$ Excluded participants without pharmacological treatment during the first treament year $(n=16)$

${ }^{\mathrm{b}} \mathrm{X}^{2}$ test

'Fixed-dose combination of two active pharmaceutical ingredients is considered as one drug

${ }^{d}$ Calculated average total daily number of pills per each patient (since the number of pills varied during a following year) was used to calculate the median of total daily number of pills for urban, rural and island enironment

${ }^{\text {KKruskal-Wallis test }}$

In the case of overall pattern of all prescribed antihypertensive agents (mono and combined therapies, 329 drugs in total), ACEI were again the most commonly prescribed $(n=83,25.2 \%)$, followed by $\beta$-adrenergic receptor antagonists $(n=60,18.2 \%)$, calcium channel blockers $(n=57,17.3 \%)$ and diuretics $(n=55,16.7 \%$, Table 6). Among the ACEI, lisinopril $(n=41,49.4 \%)$ and ramipril $(n=25,30.1 \%)$ were the most widely prescribed. Thiazide-like diuretics, chlortalidone $(n=30,54.5 \%)$ and indapamide $(n=18,32.7 \%)$, were the most commonly used among single-agent diuretics. Thiazide diuretics were prescribed only in fixed-dose combinations that were available on the Croatian drug market. Among fixed-dose combinations, the most frequently applied in the first year of treatment was lisinopril in combination with hydrochlorothiazide $(n=23,37.1 \%)$.

Prescribed anthypertensive drug classes did not differ among patients who achieved control of $\mathrm{AH}$ and those who did not $(P=0.205$, see Additional file 1: Table S2). Lisinopril $(n=27,15.4 \%)$ and bisoprolol $(n=22,12.6 \%$,

Table 6 Prescription rates in treating newly diagnosed arterial hypertension in South Croatia

\begin{tabular}{|c|c|c|}
\hline \multirow[t]{2}{*}{ Prescribed antihypertensive class } & \multicolumn{2}{|c|}{ Proportion of medication prescribed, n, (\%) } \\
\hline & Monotherapy $^{a}$ & Overall prescriptions ${ }^{a}$ \\
\hline Diuretics: & $9(11.7)$ & $55(16.7)$ \\
\hline Thiazide-like diuretics & $9(11.7)$ & $48(14.6)$ \\
\hline Loop diuretics & $0(0.0)$ & $6(1.8)$ \\
\hline Aldosterone antagonists & $0(0.0)$ & $1(0.3)$ \\
\hline Angiotensin-converting enyzme inhibitors ${ }^{a}$ & $27(35.1)$ & $83(25.2)$ \\
\hline Calcium channel blockers & $18(23.4)$ & $57(17.3)$ \\
\hline Angiotensin II receptor blockers & $1(1.3)$ & $11(3.3)$ \\
\hline Antiadrenergic agents ${ }^{\mathrm{b}}$ & $22(28.6)$ & $61(18.5)$ \\
\hline Fixed-dose combinations & / & $62(18.8)$ \\
\hline
\end{tabular}

${ }^{a}$ Excluded: patients without any pharmacological treatment $(n=16)$. There were 77 patients receiving only one antihypertensive drug during the first treament year. A total of 330 drugs were prescribed to 197 patients during one year and considered for the overall utilization, including mono and combined therapies, that were at least once prescribed to one newly diagnosed hypertensive during one-year treatment. The required data for one ACE inhibitor was missing, leaving 329 drugs for analysis

bonly beta-adrenergic blocking agents in the monotherapy group $(n=22)$. Beta blockers were predominant overall $(n=60)$, only one was selective alpha-2 adrenergic and imidazoline receptor agonist 
see Additional file 1: Table S3) were the most commonly used considering 115 patients which were normotensive after 1 year of pharmacological treatment.

\section{Discussion}

Our study demostrated that the sucess in controlling uncomplicated essential hypertension in a family medicine setting within the first year of treatement was relatively high $(57.3 \%)$ and similar in different geographical settings: in the second largest city in Croatia (Split) and its more geographically isolated hinterland and islands, regardless of socioeconomic inequalities [37, 38], access to health care and differences in prescribing patterns. Our findings are in contrast with reported positive association between socioeconomic variety and normotension rates found in most international studies [14, 39-41], as well as frequent insufficient hypertension managament in general practice $[42,43]$.

In an indirect manner, these findings correspond to a recent study in this region, which found that general health status in this area did not differ with respect to the geographical and socioeconomic factors [37]. It is important to emphasize that our study addressed only patients with uncomplicated hypertension treatment. We excluded the patients with diabetes since it was shown to be associated with higher systolic and diastolic BP values [44] and a negative predictor of BP control [45]. The rates of achieving normotension were relatively high, compared to $32.5 \%$ of the patients receiving treatment and controlled in the international community-based Prospective Urban Rural Epidemiology (PURE) study [39]. However, our results are generally consistent with the findings from recent European studies [46-48] and demonstrate an increase in the rate of achieving the targeted BP in Croatia when compared to the rate of $19.4 \%$ from the EH-UH study published in 2007 [49]. However, it has to be highlighted that in almost all of the aforementioned studies, study population included diabetic hypertensive patients [39, 41, 44-49]. In a comparative study of three different European communities, England, Belgium and Italy, with diabetes mellitus as one of exclusion criteria, the rates of achieving normotension among those treated were 42.0, 43.0 and 47.7\%, respectively [50]. Canadian middle-aged hypertensive patients without diabetes mellitus or cardiovascular diseases had almost similar sucess rate of 57.4\% [51].

The second important finding of our study was that the different antihypertensive drugs and treatment choices led to similar effectiveness in BP control. ACE inhibitors were the most widely prescribed antihypertensive single drug therapy in the first-line in rural (28.0\%) and island areas (22.7\%), whilst calcium channel blockers predominated in urban setting $(28.6 \%)$. The choice of initial treatment was in line with the 2013 guidelines of the European Society of Hypertension (ESH) and European Society of Cardiology (ESC), which recommended the following five pharmacotherapeutic groups for the initiation and maintenance of antihypertensive treatment - diuretics, $\beta$-blockers, calcium channel blockers, ACE inhibitors and angiotensin receptor II blockers, as monotherapy or combined polytherapy [17]. However, there was a significant disagreement with the recommendations of most other international guidelines, valid in the time of conducting our research, for the $\beta$-blockers, which were, except in $2013 \mathrm{ESH} / \mathrm{ESC}$ guidelines [17], mainly recommended as a third [19] or a fourth-line treatment $[16,18,20]$. The first-line $\beta$-blockers were not prominent in the Eighth Joint National Committee (JNC 8) guidelines from 2014 [20], due to higher rate of the primary composite outcome of cardiovascular death, myocardial infarction, and increased risk of stroke compared to use of losartan [52] and other antihypertensive drugs [53]. The proportion of $\beta$-blockers in the initial treatment was higher on the islands (21.2\%), in comparison with Dalmatian Hinterland (10.7\%) and Split (8.9\%). It is interesting that physicians in urban and rural environment replaced beta-blockers with recommended first-line therapy options, whilst island family physicians sustain this older therapeutic approach [54]. Possible reasons underlying this practice are not clear and should be further investigated.

Diuretics are the first-line therapy choice for most hypertensive patients according to the recommendations of the Seventh Joint National Committee (JNC 7) guidelines [55] as well as guidelines of the World Health Organization and the International Society of Hypertension from 2003 [56]. Thiazide-like diuretics [16, 17, 20] and thiazide diuretics [17-19] are initially recommended in almost all mentioned international guidelines for the management of arterial hypertension. In spite of that, diuretics administered alone in the first-line were prescribed to only $1.5 \%$ of the patients at practices on the Croatian islands, $5.4 \%$ in the city of Split and $10.7 \%$ in the rural area (Table 5). It has been shown that most general practitioners consider diuretics as too weak to treat arterial hypertension effectively in monotherapy [57], which could support this prescribing pattern in South Croatia, and they appear to be initial antihypertensive class with the lowest persistance rate as well [58]. Nonetheless, it should be mentioned that the availability of thiazide diuretics only in fixed-dose combinations on the drug market in Croatia could bias our results, limiting physicians' choice to two-drug regimen immediately after the initial diagnosis. The higher proportion of diuretics in the initial treatment in the rural setting is in line with the results from the study conducted in Split and Trilj, another representative of Dalmatian rural area (2005-2010) [59]. The ingrained 
perception of diuretics as inexpensive drugs [60] could be one of possible reason underlying this primary care prescribing behavior in the rural area with assumed lower socioeconomic status.

Since better BP reduction is often achieved by combining drugs from two different classes in comparison with doubling the dose of one drug [61] and with fixed-dose combinations there is also significant improvement in the compliance [62], the frequency of fixed-dose combinations could have been higher $(18.8 \%$ during the first year of treatment). Hence, it might be required to further investigate reasons of relatively low rates of prescribing fixed-dose combinations among physicians in order to increase the rate of achieving normotension even more.

Taking into account that we found only a single physician from rural area with significantly higher total annual cost of prescribed drugs for treating one newly diagnosed hypertensive patient, it is difficult to make judgements on differences in the costs of $\mathrm{AH}$ treatment across different regions. However, comparing the highest annual average antihypertensive drugs cost in this study (290.3 Croatian kunas, approximately $38.9 €, 95 \% \mathrm{CI}=$ 214.1-394.7 Croatian kunas) with the cost of $€ 258$ during follow-up period of $36 \pm 3$ months in French general practices [63], it could be concluded that the cost of drugs for treating high blood pressure in Croatia is relatively low. Our findings suggest that different BP-lowering agents have similar financial effects, but the small sample sizes did not allow stronger conclusions. Despite noticed decreasing trend of the primary care expenditure considering the overall healthcare expenditure in Croatia from 1989 to 2000 [26], there were no differences among physicians in prescribing drugs from two Croatian National Medicine Reimbursement Lists.

Primary care is an important interface between the patients and the health care system, shown to be associated with improved health outcomes [64]. The results of our study indicate that family medicine physicians in Croatia could be the cornerstone in controlling arterial hypertension. However, discordance found comparing international hypertension prevalence rates and recorded prevalence in family medicine practices in Croatia, which was lower than $10 \%$ in 2001 [26], emphasize the need for more effective coverage of the population by family medicine services, and the improvement of screening programmes and detection at the primary care level.

The key strenght of this study lies in its comprehensive analysis of the effectiveness of newly diagnosed arterial hypertension treatment in primary care setting. It provides insight into the impact of primary care in the achieving control of uncomplicated essential hypertension in the real-life socio-economic conditions. The major limitation of the study is its retrospective character. Furthermore, due to the inability to access two
Croatian National Medicine Reimbursement Lists valid in time periods that involved one-year following intervals, original drug packaging prices were taken from the Croatian National Medicine Reimbursement Lists which were valid during the data extraction, in force since May 2015 [35]. Finally, the calculation of direct cost of hypertension treatment should include all other medical, as well as non-medical direct costs [65] to assess the full the cost of treating $\mathrm{AH}$.

\section{Conclusion}

To conclude, there is a remarkable lack of association between socioeconomic conditions and uncomplicated arterial hypertension control in primary care setting. Different antihypertensive prescribing patterns seem do not have an impact on the effectiveness in blood pressure control after the one-year treatment. Family physicians seem to be able, without any intervention by medical specialists, to achieve normotension in newly diagnosed patients with arterial hypertension, emphasizing their key role in dealing with this major public health problem.

\section{Additional file}

\section{Additional file 1: Table S1. General characteristics of patients according to their blood pressure control after one-year treatment. Table S2. Prescribed pharmacological subgroups for patients with and without achieved blood pressure control after one-year treatment. Table S3. Prescribed generic names for patients with and without achieved blood pressure control after one-year treatment. (DOCX $68 \mathrm{~kb}$ )}

\section{Abbreviations \\ ACEl: Angiotensin-converting enzyme inhibitor; $\mathrm{AH}$ : Arterial hypertension; ANOVA: Analysis of variance; ARB: Angiotensin receptor II blockers; BB: $\beta$ - adrenergic receptor antagonists; BP: Blood pressure; CCB: Calcium channel blockers; CHIF: Croatian Health Insurance Fund; Cl: Confidence interval; DDD: Defined daily dose; EH-UH Study: Epidemiology of Hypertension in Croatia; ESH/ESC: European Society of Hypertension/European Society of Cardiology; HRK: Croatian kuna; JNC 7: Seventh Joint National Committee; JNC 8: Eighth Joint National Committee; MAP: Mean arterial pressure; OR: Odds ratio; PURE: Prospective Urban Rural Epidemiology study; VAT: Value-added tax}

Acknowledgements

Not applicable.

\section{Funding}

This study was funded in part by the grant from the Croatian Science Foundation, grant No. IP-2014-09-7672 ("Professionalism in Health Care"). The funder had no role in the design of this study, during its execution and data interpretation

\section{Availability of data and materials}

The datasets used and/or analysed during the current study are available from the corresponding author.

Authors' contributions

IP, VŠ, NMĐ, AK, MV, DMV, PŠ, TP, MJ, DL and DJ collected data on patients from family medicine offices. MMal and IB performed the statistical analysis, and together with IP, AM, MMar and DJ interpreted the patient data. AM, MMar, IP and DJ drafted the work, and others 
revised it critically. All authors read and approved the final manuscript. All authors agree to be accountable for all aspects of the work in ensuring that questions related to the accuracy or integrity of any part of the work are appropriately investigated and resolved.

\section{Ethics approval and consent to participate}

Not applicable. The study used the data from the archives of family medicine practices. The data were provided by the participating doctors as fully anonymized data sets.

\section{Consent for publication}

Not applicable.

\section{Competing interests}

The authors declare that they have no competing interests.

\section{Publisher's Note}

Springer Nature remains neutral with regard to jurisdictional claims in published maps and institutional affiliations.

\section{Author details}

${ }^{1}$ Department of Pharmacology, University of Split School of Medicine, Šoltanska 2, Split, Croatia. ${ }^{2}$ Department of Family Medicine, University of Split School of Medicine, Split, Croatia. ${ }^{3}$ Family medicine practice, Split, Croatia. ${ }^{4}$ Department of Research in Biomedicine and Health, University of Split School of Medicine, Split, Croatia. ${ }^{5}$ Family medicine practice, Lećevica, Croatia. ${ }^{6}$ Family medicine practice, Postira, Croatia. ${ }^{7}$ Family medicine practice, Korčula, Croatia. ${ }^{8}$ Family medicine practice, Imotski, Croatia. ${ }^{9}$ Family medicine practice, Pučišća, Croatia. ${ }^{10}$ Family medicine practice, Runovići, Croatia.

${ }^{11}$ Family medicine practice, Donji Muć, Croatia. ${ }^{12}$ Department of Pharmacy, University of Split School of Medicine, Split, Croatia.

Received: 15 July 2018 Accepted: 2 January 2019

Published online: 14 January 2019

\section{References}

1. GBD 2015 Risk Factors Collaborators. Global, regional, and national comparative risk assessment of 79 behavioural, environmental and occupational, and metabolic risks or clusters of risks, 1990-2015: a systematic analysis for the Global Burden of Disease Study 2015. Lancet. 2016;388(10053):1659-724.

2. NCD Risk Factor Collaboration (NCD-RisC). Worldwide trends in blood pressure from 1975 to 2015: a pooled analysis of 1479 population-based measurement studies with 19.1 million participants. Lancet. 2017;389(10064):37-55.

3. Sarki AM, Nduka CU, Stranges S, Kandala NB, Uthman OA. Prevalence of hypertension in low- and middle-income countries: a systematic review and meta-analysis. Medicine. 2015:94(50):e1959.

4. Cournot M, Lenclume V, Le Moullec N, Debussche X, Doussiet E, FagotCampagna $\mathrm{A}$, et al. Prevalence, treatment and control of hypertension in La Reunion: the REDIA population-based cohort study. Blood Press. 2017; 26(1):39-47.

5. Menendez E, Delgado E, Fernandez-Vega F, Prieto MA, Bordiu E, Calle A, et al. Prevalence, diagnosis, treatment, and control of hypertension in Spain. Results of the Di@bet.es study. Rev Esp Cardiol (Engl Ed). 2016;69(6):572-8.

6. Yang L, Yan J, Tang X, Xu X, Yu W, Wu H. Prevalence, awareness, treatment, control and risk factors associated with hypertension among adults in southern China, 2013. PLoS One. 2016;11(1):e0146181.

7. Camara A, Balde NM, Diakite M, Sylla D, Balde EH, Kengne AP, et al. High prevalence, low awareness, treatment and control rates of hypertension in Guinea: results from a population-based STEPS survey. J Hum Hypertens. 2016;30(4):237-44.

8. Yoon SS, Carroll MD, Fryar CD. Hypertension prevalence and control among adults: United States, 2011-2014. NCHS Data Brief. 2015;220:1-8.

9. Akinlua JT, Meakin R, Umar AM, Freemantle N. Current prevalence pattern of hypertension in Nigeria: a systematic review. PLoS One. 2015;10(10):e0140021.

10. Heiniger S, Viswanathan B, Gedeon J, Paccaud F, Bovet P. Trends in prevalence, awareness, treatment and control of high blood pressure in the Seychelles between 1989 and 2013. J Hypertens. 2017;35(7):1465-73.

11. Yusuf S, Reddy S, Ounpuu S, Anand S. Global burden of cardiovascular diseases: part II: variations in cardiovascular disease by specific ethnic groups and geographic regions and prevention strategies. Circulation. 2001; 104(23):2855-64.

12. Boukli Hacene L, Khelil MA, Chabane Sari D, Meguenni K, Meziane Tani A. Prevalence of cardiovascular risk factors in urban and rural communities in the Wilaya of Tlemcen (Algeria): a comparative study. Rev Epidemiol Sante Publique. 2017;65(4):277-84.

13. Zaman MM, Rahman MM, Rahman MR, Bhuiyan MR, Karim MN, Chowdhury MA. Prevalence of risk factors for non-communicable diseases in Bangladesh: results from STEPS survey 2010. Indian J Public Health. 2016;60(1):17-25.

14. Guo J, Yu C, Lyu J, Guo Y, Bian Z, Zhou H, et al. Status of prevalence, awareness, treatment and controll on hypertension among adults in 10 regions. China. Zhonghua Liu Xing Bing Xue Za Zhi. 2016;37(4):469-74.

15. Akpan EE, Ekrikpo UE, Udo Al, Bassey BE. Prevalence of hypertension in Akwa Ibom State, South-South Nigeria: rural versus urban communities study. Int J Hypertens. 2015:2015:975819.

16. National Institute for Health and Clinical Excellence (NICE). Hypertension in adults: diagnosis and management. London: NICE; 2011. (updated 2016). Available at: http://guidance.nice.org.uk/CG127. Accessed 6 Oct 2017

17. Mancia G, Fagard R, Narkiewicz K, Redon J, Zanchetti A, Bohm M, et al. 2013 ESH/ESC guidelines for the management of arterial hypertension: the task force for the management of arterial hypertension of the European Society of Hypertension (ESH) and of the European Society of Cardiology (ESC). J Hypertens. 2013;31(7):1281-357.

18. Weber MA, Schiffrin EL, White WB, Mann S, Lindholm LH, Kenerson JG, et al. Clinical practice guidelines for the management of hypertension in the community: a statement by the American Society of Hypertension and the International Society of Hypertension. J Clin Hypertens (Greenwich). 2014; 16(1):14-26.

19. Go AS, Bauman MA, Coleman King SM, Fonarow GC, Lawrence W, Williams $K A$, et al. An effective approach to high blood pressure control: a science advisory from the American Heart Association, the American College of Cardiology, and the Centers for Disease Control and Prevention. Hypertension. 2014;63(4):878-85.

20. James PA, Oparil S, Carter BL, Cushman WC, Dennison-Himmelfarb C, Handler J, et al. 2014 evidence-based guideline for the management of high blood pressure in adults: report from the panel members appointed to the Eighth Joint National Committee (JNC 8). JAMA. 2014;311(5):507-20.

21. Chmiel C, Wang M, Senn O, Del Prete V, Zoller M, Rosemann T, et al. Uncontrolled arterial hypertension in primary care--patient characteristics and associated factors. Swiss Med Wkly. 2012;w13693:142.

22. Tschudi P, Martina B. Hypertension in general practice in Switzerland. Rev Med Suisse. 2010;6(249):1011-2 1014-5.

23. Paulsen MS, Andersen M, Thomsen JL, Schroll H, Larsen PV, Lykkegaard J, et al. Multimorbidity and blood pressure control in 37651 hypertensive patients from Danish general practice. J Am Heart Assoc. 2012;2(1):e004531.

24. Kika TM, Lepira FB, Kayembe PK, Makulo JR, Sumaili EK, Kintoki EV, et al. Uncontrolled hypertension among patients managed in primary healthcare facilities in Kinshasa, Democratic Republic of the Congo. Cardiovasc J Afr. 2016;27(6):361-6.

25. U.S. Department of Health and Human Services, Centers for Disease Control and Prevention. National Ambulatory Medical Care Survey: 2010 Summary Tables. Atlanta: Centers for Disease Control and Prevention; 2013. Available at: http://www.cdc.gov/nchs/data/ahcd/namcs_summary/2010_namcs web_tables.pdf. Accessed 12 Dec 2018

26. Katic M, Juresa V, Oreskovic S. Family medicine in Croatia: past, present, and forthcoming challenges. Croat Med J. 2004;45(5):543-9.

27. The National High Blood Pressure Education Program Working Group. National High Blood Pressure Education Program Working Group report on hypertension in diabetes. Hypertension. 1994;23(2):145-58 discussion 59-60.

28. Sowers JR, Epstein M, Frohlich ED. Diabetes, hypertension, and cardiovascular disease: an update. Hypertension. 2001;37(4):1053-9.

29. Chahoud J, Mrad J, Semaan A, Asmar R. Prevalence of diabetes mellitus among patients with essential arterial hypertension. J Med Liban. 2015;63(2):74-80.

30. Gress TW, Nieto FJ, Shahar E, Wofford MR, Brancati FL. Hypertension and antihypertensive therapy as risk factors for type 2 diabetes mellitus. Atherosclerosis Risk in Communities Study. N Engl J Med. 2000;342(13):905-12.

31. Katić M. Status and functioning of family medicine in Croatia. In: Katić M, Švab I, associates, editors. Family medicine. Zagreb: Medicinska naklada; 2017. p. 19-25.

32. Dzakula A, Sagan A, Pavic N, Lonccarek K, Sekelj-Kauzlaric K. Croatia: health system review. Health Syst Transit. 2014;16(3):1-162 xvii-xviii. 
33. Vitezic D, Madjarevic T, Gantumur M, Buble T, Vitezic M, Kovacevic M, et al. Drug usage by outpatients in Croatia during an 8-year period: influence of changes in pricing policy. Int J Clin Pharmacol Ther. 2012;50(7):483-9.

34. Culig J, Antolic S, Szkultecka-Debek M. Drug policy in Croatia. Value Health Reg Issues. 2017;13:27-30.

35. Croatian Health Insurance Fund. CHIF: Search for medicines. Zagreb: Croatian Health Insurance Fund; 2015. Available at: http://www.hzzo.hr/ zdravstveni-sustav-rh/trazilica-za-lijekove-s-vazecih-lista/arhiva-liste-lijekova/. Accessed 17 Sep 2015

36. National Institutes of Health. Your guide to lowering your blood pressure with DASH. Bethesda: National Institutes of Health; 2016. Available at https://www. nhlbi.nih.gov/files/docs/public/heart/new_dash.pdf. Accessed 9 Mar 2016

37. Stipcic A, Coric T, Erceg M, Mihanovic F, Kolcic I, Polasek O. Socioeconomic inequalities show remarkably poor association with health and disease in southern Croatia. Int J Public Health. 2015:60(4):417-26.

38. Bergman Markovic B, Vrdoljak D, Kranjcevic K, Vucak J, Kern J, Bielen I, et al. Continental-Mediterranean and rural-urban differences in cardiovascular risk factors in Croatian population. Croat Med J. 2011;52(4):566-75.

39. Chow CK, Teo KK, Rangarajan S, Islam S, Gupta R, Avezum A, et al. Prevalence, awareness, treatment, and control of hypertension in rural and urban communities in high-, middle- and low-income countries. JAMA. 2013;310(9):959-68.

40. Agyemang C, van Valkengoed I, Koopmans R, Stronks K. Factors associated with hypertension awareness, treatment and control among ethnic groups in Amsterdam, the Netherlands: the SUNSET study. J Hum Hypertens. 2006; 20(11):874-81

41. Li W, Gu H, Teo KK, Bo J, Wang Y, Yang J, et al. Hypertension prevalence, awareness, treatment, and control in 115 rural and urban communities involving 47000 people from China. J Hypertens. 2016;34(1):39-46.

42. Nicodeme R, Albessard A, Amar J, Chamontin B, Lang T. Poor blood pressure control in general practice: in search of explanations. Arch Cardiovasc Dis. 2009:102(6-7):477-83.

43. Howes F, Hansen E, Williams D, Nelson M. Barriers to diagnosing and managing hypertension - a qualitative study in Australian general practice. Aust Fam Physician. 2010;39(7):511-6.

44. Vitezic D, Burke T, Mrsic-Pelcic J, Mavric Z, Zaputovic L, Zupan G, et al. Characteristics of blood-pressure control in treated hypertensive patients in Croatia. Blood Press Suppl. 2005;2:33-41.

45. Cushman WC, Ford CE, Cutler JA, Margolis KL, Davis BR, Grimm RH, et al. Success and predictors of blood pressure control in diverse North American settings: the antihypertensive and lipid-lowering treatment to prevent heart attack trial (ALLHAT). J Clin Hypertens (Greenwich). 2002;4(6):393-404.

46. Tocci G, Muiesan ML, Parati G, Agabiti Rosei E, Ferri C, Virdis A, et al. Trends in prevalence, awareness, treatment, and control of blood pressure recorded from 2004 to 2014 during World Hypertension Day in Italy. J Clin Hypertens (Greenwich). 2016;18(6):551-6.

47. Banegas JR, Graciani A, de la Cruz-Troca JJ, Leon-Munoz LM, GuallarCastillon P, Coca A, et al. Achievement of cardiometabolic goals in aware hypertensive patients in Spain: a nationwide population-based study. Hypertension. 2012;60(4):898-905.

48. Murphy CM, Kearney PM, Shelley EB, Fahey T, Dooley C, Kenny RA Hypertension prevalence, awareness, treatment and control in the over 50s in Ireland: evidence from the Irish longitudinal study on ageing. J Public Health (Oxf). 2016;38(3):450-8.

49. Jelakovic B, Zeljkovic-Vrkic T, Pecin I, Dika Z, Jovanovic A, Podobnik D, et al. Arterial hypertension in Croatia. Results of EH-UH study. Acta Med Croatica. 2007;61(3):287-92.

50. Costanzo S, Di Castelnuovo A, Zito F, Krogh V, Siani A, Arnout J, et al. Prevalence, awareness, treatment and control of hypertension in healthy unrelated male-female pairs of European regions: the dietary habit profile in European communities with different risk of myocardial infarction--the impact of migration as a model of gene-environment interaction project. J Hypertens. 2008;26(12):2303-11

51. Gupta M, Szmitko P, Singh N, Tsigoulis M, Kajil M, Stone J. Contemporary management and control of uncomplicated hypertension in Canada: insight from the primary care audit of global risk management (PARADIGM) study. Can J Cardiol. 2015;31(5):664-70.

52. Dahlof B, Devereux RB, Kjeldsen SE, Julius S, Beevers G, de Faire U, et al. Cardiovascular morbidity and mortality in the Losartan Intervention For Endpoint reduction in hypertension study (LIFE): a randomised trial against atenolol. Lancet. 2002;359(9311):995-1003.
53. Lindholm LH, Carlberg B, Samuelsson O. Should beta blockers remain first choice in the treatment of primary hypertension? A meta-analysis. Lancet. 2005;366(9496):1545-53.

54. Larochelle P, Tobe SW, Lacourciere Y. Beta-blockers in hypertension: studies and meta-analyses over the years. Can J Cardiol. 2014;30(5 Suppl):S16-22.

55. Chobanian AV, Bakris GL, Black HR, Cushman WC, Green LA, Izzo JL Jr, et al. The seventh report of the Joint National Committee on prevention, detection, evaluation, and treatment of high blood pressure: the JNC 7 report. JAMA. 2003;289(19):2560-72.

56. Whitworth JA. 2003 World Health Organization (WHO)/International Society of Hypertension (ISH) statement on management of hypertension. J Hypertens. 2003;21(11):1983-92.

57. Lamers H, Joos S, Goetz K, Hermann K, Szecsenyi J, Kuhlein T. Diuretics for hypertension-reasons for a contradiction in primary care prescribing behavior: a qualitative study. J Clin Hypertens (Greenwich). 2012;14(10):680-5.

58. Bramlage $P$, Hasford J. Blood pressure reduction, persistence and costs in the evaluation of antihypertensive drug treatment--a review. Cardiovasc Diabetol. 2009:8:18.

59. Cikara A, Pavlicevic I, Peric I. Level of hypertension control: comparison of a rural and urban family practice centre in South Croatia. Wien Klin Wochenschr. 2013;125(7-8):173-9.

60. Fischer MA, Avorn J. Economic implications of evidence-based prescribing for hypertension: can better care cost less? JAMA. 2004;291(15):1850-6.

61. Wald DS, Law M, Morris JK, Bestwick JP, Wald NJ. Combination therapy versus monotherapy in reducing blood pressure: meta-analysis on 11,000 participants from 42 trials. The Am J Med. 2009;122(3):290-300.

62. Gupta AK, Arshad S, Poulter NR. Compliance, safety, and effectiveness of fixed-dose combinations of antihypertensive agents: a meta-analysis. Hypertension. 2010;55(2):399-407.

63. Tibi-Levy Y, de Pouvourville G, Westerloppe J, Bamberger M. The cost of treating high blood pressure in general practice in France. Eur J Health Econ. 2008;9(3):229-36.

64. Finley CR, Chan DS, Garrison S, Korownyk C, Kolber MR, Campbell S, et al. What are the most common conditions in primary care? Systematic review. Can Fam Physician. 2018:64(11):832-40.

65. Paczkowska A, Koligat D, Nowakowska E, Hoffmann K, Bryl W. Analysis of direct costs of hypertension treatment among adolescents in Poland. Acta Pol Pharm. 2014;71(1):197-203.
Ready to submit your research? Choose BMC and benefit from:

- fast, convenient online submission

- thorough peer review by experienced researchers in your field

- rapid publication on acceptance

- support for research data, including large and complex data types

- gold Open Access which fosters wider collaboration and increased citations

- maximum visibility for your research: over $100 \mathrm{M}$ website views per year

At $\mathrm{BMC}$, research is always in progress.

Learn more biomedcentral.com/submission 